\title{
PENGARUH CUSTOMER EXPERIENCE DAN TRUST TERHADAP LOYALITAS PELANGGAN KFC DI KOTA BENGKULU
}

\author{
Ade Tiara Yulinda ${ }^{1}$, Furqonti Ranidiah ${ }^{2}$, Wahyu Rizqiya Ratna Jauhari ${ }^{3}$ \\ ${ }^{1,2 \& 3}$ Universitas Muhammadiyah Bengkulu \\ $\underline{\text { ade91tiarayulinda@gmail.com }}{ }^{1}, \underline{\text { furqonti.ranidiah@gmail.com }{ }^{2} \text {,wahyurizqiva123@gmail.com }}{ }^{3}$
}

\begin{abstract}
This study aims to determine the effect of the customers' experiences and Trust on KFC customer loyalty in the city of Bengkulu. This research is a quantitative study with a sample of 100 respondents, and used accidental sampling techniques. The data was collected through observation and questionnaires. The data was analyzed through descriptive analysis, the classic assumption test, multiple linear regression analysis, correlation coefficient analysis, coefficient of determination $\left(R^{2}\right)$, and hypothesis testing. The results of this study showed that from the multiple linear regression test using SPSS it was obtained $Y=2,244+0,292 X 1+$ 0,675 X2. The results of hypothesis testing showed that Customer Experience (X1) has a positive effect on KFC customer loyalty in Bengkulu City, with the T-test results of significance value $0.000<0.05$, Trust (X2) has a positive effect on KFC customer loyalty in Bengkulu City, with T-test results of significance value 0,000 $<0.05$. The testing of the T-test hypothesis and the F-test showed that customers' experience and Trust significantly affect customers' loyalty with a significance level <0.05. This means that Ho was rejected and Ha was accepted. In other words, customers' experiences and Trust have a significant effect both partially and simultaneously on KFC customers' loyalty. This is proven by the f test that showed a significance value of $0.000<0.05$.
\end{abstract}

Keywords: Customers' Experiences and Trust, and Customers' Loyalty

\section{PENDAHULUAN}

Perkembangan bisnis saat ini semakin meningkat dengan pesat seiring dengan masyarakat yang semakin kritis dalam memilih dan memenuhi kebutuhan hidup yang sangat beragam. Dengan perkembangan bisnis yang semakin pesat saat ini banyak bermunculan bisnis-bisnis yang menawarkan produk-produk unggulan yang dibutuhkan oleh masyarakat modern salah satunya restoran cepat saji. Restoran cepat saji semakin meningkat dan disukai oleh masyarakat saat ini, sebagai perubahan gaya hidup modern dengan fleksibilitas.

Persaingan bisnis restoran cepat saji cepat semakin ketat, dilihat dengan banyaknya perusahaan serupa dalam melakukan bisnis makanan siap saji yang ada di Bengkulu, salah satunya adalah KFC (Kentucky Fried Chicken), CFC (California Fried Chicken), Allbaik Chicken, Labbaik Chicken, Zest Fried Chicken, Karomah Chicken, McDonald's, Pizza Hut, Dll. Dengan persaingan yang semakin ketat membuat para pelaku bisnis berlomba lomba untuk memenangkan persaingan pasar, salah satu yaitu dengan kemampuan restoran 
cepat saji dalam meningkatkan pengalaman dan kepercayaan pelanggan. Untuk dapat mempertahankan pelanggan yang lama dan konsumen baru, restoran cepat saji harus mampu memberikan pengalaman-pengalaman secara positif kepada konsumen sehingga bisa memberikan kepercayaan terhadap konsumen.

Experience adalah ketika seorang pelanggan mendapatkan sensasi atau pengetahuan yang dihasilkan dari beberapa tingkat interaksi dengan berbagai elemen yang diciptakan oleh penyedia layanan. Sensasi atau pengetahuan yang didapat tersebut akan secara otomatis tersimpan dalam memori pelanggan (Gupta dan Vajic dalam Nasermoadeli, 2012:129). Dengan adanya pengalaman positif yang diterima konsumen akan memberikan kenangan tersediri sehingga konsumen akan menceritakan pengalaman tersebut kepada orang lain untuk tertarik mengkonsumsi produk tersebut.

Trust juga sangat penting bagi perusahaan karena kepercayaan pelanggan merupakan salah satu keberhasilan restoran. Kepercayaan merupakan kondisi mental yang didasarkan oleh situasi seseorang dan konteks sosialnya. Ketika seseorang mengambil suatu keputusan, ia akan lebih memilih keputusan berdasarkan pilihan dari orang-orang yang lebih dapat ia percaya dari pada yang kurang dipercayai (Moorman, 2009:8) dikutip oleh Deni Pranoto (2014:14). Perusahaan restoran siap saji harus memberikan pelayanan terbaik dengan cara memberikan pengalaman yang positif untuk meningkatkan dan mendapatkan kepercayaan pengunjung, yang demikian itu akan menimbulkan loyalitas pelanggan.

Loyalitas merupakan sesuatu yang timbul tanpa adanya paksaan tetapi timbul dengan sendirinya. Menurut Kotler dan Keller (2010: 138) loyalitas adalah komitmen yang dipegang secara mendalam untuk membeli atau mendukung kembali produk atau jasa yang disukai di masa depan meski pengaruh situasi dan usaha pemasaran berpotensi menyebabkan pelanggan beralih. Defenisi lain dari Tjiptono (2011:481) loyalitas pelanggan adalah pembelian ulang semata mata menyangkut pembelian merek tertentu yang sama secara berulang kali. Dengan pembelian yang dilakukan pelanggan secara terus-menerus dapat memberikan keuntungan jangka panjang bagi perusahaan.

KFC (dulu dikenal dengan nama Kentucky Fried Chicken) adalah suatu merk dagang waralaba dari Yum! Brands, Inc., Bermarkas di Louisville, Kentucky, Amerika serikat. Didirikan oleh Colonel Harland Sanders, pada tahun 1952. Di Indonesia, pemegang hak waralaba tunggal KFC adalah PT. Fastfood Indonesia Tbk, yang didirikan oleh kelompok usaha Gelael pada tahun 1978 dan di buka tahun 1979 di jalan Melawai, Jakarta. (http://id.wikipedia.org/wiki/KFC).

Berdasarkan hasil wawancara beberapa pelanggan yang dimintai pendapat mengenai KFC di Kota Bengkulu oleh Permadi pukul 13.00 hari Jum'at 13/12/2019, dan Deka pukul 16.00 hari Jum'at 13/12/2019. Masih terdapatnya pelanggan yang mengeluh suatu produk sehingga bisa menurunkan loyalitas 
pelanggan, seperti KFC kurangnya memproduksi iklan yang menampilkan bagaimana cara KFC memproses ayam atau cara pemotonganya sehingga layak dan aman untuk dikonsumsi masayarakat. Sehingga menurut pelanggan masih meragukan, akibatnya bisa mengurangi kepercayaan pelanggan terhadap produk di KFC. Kualitas pelayanan yang diberikan kurang karena seringkali pembelian ayam paketan bisa menunggu 15 menit hingga 20 menit menunggu ayam yang belum di goreng sehingga konsumen merasa kesal karena terlalu lama menunggu. Harga yang ditawarkan KFC cukup mahal dikarenakan konsumen dikenai pajak, jangkauan pembeli di KFC ini mengarah menengah ke atas, sehingga masyarakat lebih memilih produk ayam goreng yang dijual di pinggir jalan yang harganya jauh lebih murah dan mudah dijumpai. Dari pemaparan di atas peneliti ingin mengkaji lebih dalam lagi mengenai: "Pengaruh Customer Experience dan Trust Terhadap Loyalitas Pelanggan KFC di Kota Bengkulu".

\section{TINJAUAN PUSTAKA}

\section{Loyalitas Pelanggan}

Loyalitas pelanggan adalah salah satu hasil yang paling penting dari sebuah bisnis restoran. Loyalitas memberikan indikator keberhasilan yang berarti untuk sebuah organisasi dalam lingkungan pasar yang kompetitif. Loyalitas konsumen menurut Hur et al. (2013) didefinisikan sebagai "komitmen yang dipegang teguh untuk membeli kembali produk pilihan atau jasa secara konsisten di masa mendatang, sehingga menyebabkan pembelian berulang produk atau jasa dengan merek yang sama, meskipun ada pengaruh situasional dan upaya pemasaran yang memiliki potensi untuk menyebab-kan perilaku beralih ke produk atau jasa dengan merek yang lain".

Menurut Griffin (2010:04), loyalitas pelanggan adalah seorang konsumen dikatakan setia atau loyal apabila konsumen menunjukkan perilaku pembelian secara teratur atau terdapat suatu kondisi dimana mewajibkan konsumen membeli paling sedikit dua kali dalam selang waktu tertentu.Griffin (2005) dalam (Sangadji dan Sopiah, 2013: 105) menyatakan bahwa pelanggan yang loyal memiliki 4 indikator sebagai berikut:

1. Melakukan pembelian secara teratur

Pelanggan membeli kembali produk yang sama yang ditawarkan oleh perusahaan.

2. Merekomendasikan produk lain

Pelanggan melakukan komunikasi dari mulut ke mulut berkenaan dengan produk tersebut terhadap orang lain.

3. Melakukan pembelian di semua lini produk

Pelanggan melakukan pembelian antarlini produk/jasa yang ditawarkan oleh perusahaan.

4. Menunjukkan kekebalan daya tarik produk sejenis dari pesaing

Pelanggan tidak tertarik terhadap tawaran produk sejenis yang dihasilkan oleh pesaing. 


\section{Customer Experience}

Menurut Meyer And Schwager (2007), Customer Experience adalah tanggapan pelanggan secara internal dan subjektif sebagai akibat dari interaksi secara langsung maupun tidak langsung dengan perusahaan. Hal ini biasanya terjadi pada bagian pembelian dan pelayanan. Menurut Terbelanche (2009) mendefinisikan Customer Experience sebagai akumulasi dari semua kejadian yang disadari pelanggan. Menurut Frow dan Payne dalam Nizar Ahmad (2015), Pengalaman Pelanggan (Customer Experience) dapat diartikan sebagai interpretasi seorang konsumen terhadap interaksi total konsumen tersebut dengan sebuah merek.

Menurut Watkins dalam Semuel dan Dharmayanti (2013), mendefinisikan bahwa Customer Experience sebagai penjelmaan sebuah brand yang mana melingkupi semua interaksi antara organisasi dengan konsumen. Pengertian di atas dapat disimpulkan Customer Experience adalah interaksi antara pelanggan dengan produk, yang menimbulkan interpretasi seorang kosumen sebelum dan sesudah pembelian terhadap suatu brand. Menurut Alma (2007:267) indikator yang digunakan untuk mengukur Customer Experience, meliputi:

1. Sense (panca indera)

Menciptakan sensory experiences melalui penglihatan, suara, sentuhan, perasaan, dan penciuman, yang memberikan kesan keindahan, kesenangan, kepuasan, melalui adanya stimuli, proses dan consequences atau hasil yang diperoleh karena adanya stimuli dan proses tersebut. Strategi sense experience ini digunakan oleh perusahaan untuk memotivasi konsumen agar menggunakan produk atau jasa perusahaan dan menyampaian nilai kepada pelanggan.

2. Feel (perasaan)

Menyentuh perasaan dan emosi konsumen secara mendalam, yang bertujuan menciptakan pengalaman afeksi berkaitan dengan produk atau jasa perusahaan sehingga menciptakan rasa gembira dan bangga.

3. Think (berfikir)

Yaitu menciptakan aspek kognitif, problem solving experiences. Think ini . akan muncul dalam pemikiran yang divergen dan convergen melalui pertama surprise yaitu sesuatu yang terjadi diluar dugaan

4. Act (tindakan)

Menyentuh pengalaman dalam gaya hidup, dan berinteraksi. Artinya bahwa act experience merupakan strategi perusahaan untuk mempengaruhi hidup konsumen dengan meningkatkan pengalaman fisik mereka, gaya hidup, serta interaksi. Konsumen akan menggunakan produk atau jasa perusahaan karena adanya pengaruh dari luar dan opini dari dalam.

5. Relate (hubungan)

Mencakup hubungan dengan orang lain, kelompok sosial seperti pekerjaan dan gaya hidup serta identitas sosial yang lebih luas. Tujuan dari relate experience adalah menghubungkan konsumen tersebut dengan budaya dan lingkungan sosial dari konsumen berada. 


\section{Trust}

Merupakan hal dari segi kepercayaan ketika satu kelompok, yaitu perusahaan dan pelanggan memiliki keyakinan antara satu dengan lainnya untuk dapat menciptakan hubungan yang saling menguntungkan. Trust diartikan sebagai kesediaan mengandalkan kemampuan, integritas, dan motivasi pihak lain untuk bertindak dalam rangka memuaskan kebutuhan dan kepentingan seseorang sebagaimana disepakati bersama secara implisit maupun eksplisit (Sheth dan Mittal, 2004).

Menurut Barnes (2011) kepercayaan adalah keyakinan bahwa seseorang akan menemukan apa yang diinginkan pada mitra kerjanya. Schurr dan Ozanne dalam Nudubisi, (2007) mendefinisikan kepercayaan sebagai keyakinan bahwa janji yang ditawarkan oleh suatu pihak dapat diandalkan dan percaya bahwa pihak tersebut akan memenuhi kewajibannya. Dari pengertian di atas dapat disimpulkan kepercayaan adalah keyakinan yang dimiliki pelanggan tentang suatu produk yang diyakini memiliki kualitas dan manfaat sehingga bisa memuaskan kebutuhan dan kepentingan pelanggan, apabila suatu kepercayaan telah ada maka akan timbulnya transaksi antara kedua belah pihak. Menurut Gefen (2003) menyatakan bahwa indikator kepercayaan terdiri dari 3 komponen yaitu:

1. Integritas (Integrity)

Merupakan persepsi konsumen bahwa perusahaan mengikuti prinsip-prinsip yang dapat diterima seperti menepati janji, berperilaku sesuai etika dan jujur. Integritas perusahaan tergantung dari konsistensi perusahaan dimasa lalu, komunikasi kredibel atau komunikasi tidak kredibel suatu perusahaan pada kelompok lain, dan apakah tindakan yang dilakukan perusahaan sesuai dengan janji atau kata-kata yang diucapkan perusahaan.

2. Kebaikan (Benevolence)

Yang didasarkan pada besarnya kepercayaan kemitraan yang memiliki tujuan dan motivasi yang menjadi kelebihan untuk organisasi lain pada saat kondisi yang baru muncul, yaitu kondisi dimana komitmen tidak terbentuk.

3. Kompetensi (Competence)

Kompetensi merupakan kemampuan untuk memecahkan permasalahan yang dihadapi oleh konsumen dan memenuhi segala keperluannya. Kemampuan mengacu pada keahlian dan karakteristik yang memungkinkan suatu kelompok mempunyai pengaruh yang dominan

\section{METODE PENELITIAN}

\section{Tempat dan Waktu Penelitian}

Penelitian ini dilaksanakan pada pelanggan KFC di Kota Bengkulu. Adapun pelaksanaan penelitian dilakukan pada tanggal 15 Januari 2020 s/d 15 Februari 2020 .

\section{Jenis Penelitian}

Jenis Penelitian ini adalah penelitian pendekatan deskriptif kuantitatif, yaitu dimana peneliti membandingkan hasil pengumpulan data dan membuktikan dengan angka pada sejumlah populasi melalui sampel yang dianggap layak untuk 
diteliti. Data Kuantitatif adalah data yang dapat diukur dalam skala numerik (Kuncoro, 2009: 145). Data kuantitatif dalam penelitian ini yaitu hasil kuisioner yang disebarkan pada pelanggan KFC di Kota Bengkulu.

\section{Populasi dan Sampel \\ Populasi}

Populasi adalah wilayah generalisasi yang terdiri atas subyek/obyek yang mempunyai kualitas dan karakteristik tertentu yang ditetapkan oleh peneliti untuk dipelajari dan kemudian ditarik kesimpulannya (Sugiyono,2014:80). Populasi dalam penelitian ini adalah adalah masyarakat yang berada di Kota Bengkulu yang pernah membeli KFC yang jumlah tidak diketahui (infinite).

\section{Sampel}

Sampel adalah bagian dari jumlah dan karakteristik yang dimiliki oleh populasi tersebut (Sugiyono, 2014:81). Teknik pengambilan sampel yang digunakan dalam penelitian ini adalah menggunakan metode non probability sampling yaitu dengan teknik accidental sampling. Menurut Sugiyono (2008:122) Accidental adalah pengambilan sampel dari setiap individu yang dijumpai secara kebetulan oleh peneliti, yaitu siapa saja yang secara keseluruhan/incindental bertemu dengan peneliti dapat digunakan sebagai sampel, bila dipandang orang yang kebetulan ditemui cocok sebagai sumber data. Dikarenakan jumlah populasinya tidak diketahui secara pasti maka untuk menentukan besarnya sampel digunakan rumus unknown populations (Frendy, 2011:53). Berdasarkan perhitungan sampel tersebut jumlah sampel dalam penelitian ini 100 orang responden. Sampel pada penelitian ini konsumen KFC di Kota Bengkulu yang siapa saja dijumpai oleh peneliti dalam melakukan proses penelitian.

\section{Teknik Pengumpulan data Observasi}

Observasi menurut Sugiyono (2012:145) observasi sebagai teknik pengumpulan data yang mempunyai ciri spesifik berkenaan dengan perilaku manusia, proses kerja, gejala-gejala alam, dan responden yang diamati tidak terlalu besar. Dalam hal ini, peneliti perlu mengunjungi lokasi penelitian untuk mengamati langsung pelanggan yang melakukan pembelian di KFC dan berbagai hal atau kondisi yang ada di lapangan.

\section{Kuesioner (Angket)}

Kuesioner merupakan teknik pengumpulan data yang dilakukan dengan cara memberi seperangkat pertanyaan atau pernyataan tertulis kepada responden untuk dijawabnya (Sugiyono, 2014:142). Tujuan penyebaran angket adalah mencari informasi yang lengkap mengenai suatu masalah dari responden tanpa merasa khawatir bila responden memberikan jawaban yang tidak sesuai dengan pertanyaan dalam pengisian daftar pertanyaan. Skala pengukuran data dalam penelitian ini adalah skala likert yang disebarkan secara langsung kepada responden. Menurut Sugiyono (2013:86) untuk keperluan kuantitatif, maka jawaban itu dapat diberi skor, sebagai berikut : 
Tabel 3.1

Instrument Skala Likert

\begin{tabular}{|l|l|l|}
\hline No. & Alternatif Jawaban & Bobot Nilai \\
\hline 1 & Sangat setuju (SS) & 5 \\
\hline 2 & Setuju (S) & 4 \\
\hline 3 & Netral (N) & 3 \\
\hline 4 & Tidak setuju (TS) & 2 \\
\hline 5 & Sangat tidak setuju (STS) & 1 \\
\hline
\end{tabular}

Sumber : Sugiyono (2013: 86)

\section{Teknik Analisis Data}

Analisis data adalah suatu keadaan untuk meneliti, memeriksa, mempelajari, membandingkan, data yang ada dan membuat indepretasi yang diperlukan. Selain itu, analisi data dapat digunakan untuk mengidentifikasi ada tidaknya masalah.

\section{Analisis Deskriptif}

Analisis deskriptif digunakan untuk menggambarkan fenomena-fenomena yang terjadi dilapangan berdasarkan variabel-variabel penelitian pengamatan dan persepsi responden terhadap variabel yang digunakan penelitian ini. Metode ratarata (mean) digunakan rumus (Cooper dan Emory, 2006).

Dimana:

$$
\operatorname{Rxy}=\frac{\sum f x}{N}
$$

$$
\begin{aligned}
F & =\text { Frekuensi jawaban responden } \\
X & =\text { Skor jawaban responden } \\
N & =\text { Jumlah sampel }
\end{aligned}
$$

Selanjutnya dihitung juga skala interval jawaban responden yang bertujuan untuk memudahkan interprestasi hasil dengan rumus (Cooper dan Emory, 2006).

Skala interval $=\frac{U-L}{K}$

Dimana :

$\mathrm{U}=$ Sko rjawaban tertinggi

$\mathrm{L}=$ Skor jawaban terendah

$\mathrm{K}=$ Skor jawaban Interval

Dari rumus diatas, maka skala interval yang digunakan dalam penelitian ini adalah sebagai berikut :

$$
\begin{aligned}
\text { Dik : skor jawaban tertinggi }(\mathrm{U}) & =5 \\
& \text { skor jawaban terendah }(\mathrm{L})=1 \\
& \text { skala interval }=\frac{5-1}{5}=\frac{4}{5}=0.80
\end{aligned}
$$

Jadi jarak (skala) setiap kelas interval sebesar 0,80. Dari skala interval tersebut, selanjutnya diinterkinerjakan ke dalam rata-rata jawaban responden dengan kriteria untuk variable $\mathrm{X}$ adalah : 
Tabel 3.2

Nilai Interval Responden

\begin{tabular}{|l|l|}
\hline $4,20-5,00$ & Sangat Baik \\
\hline $3,40-4,19$ & Baik \\
\hline $2,60-3,39$ & Netral \\
\hline $1,80-2,59$ & Tidak Baik \\
\hline $1,00-1,79$ & Sangat Tidak Baik \\
\hline
\end{tabular}

Penelitian ini menggunakan skala ordinal, menurut Sugiyono (2010:98) "skala ordinal adalah skala pengukuran yang tidak hanya menyatakan kategori, tetapi juga menyatakan peringkat construct yang tidak diukur". Misalnya tingkat kepuasan seseorang terhadap sebuah produk.

\section{Uji Validitas}

Uji validitas adalah sebuah alat yang digunakan untuk mengukur sah atau tidaknya suatu kuesioner. Valid berarti instrument tersebut dapat digunakan untuk mengukur apa yang sebenarnya diukur (Sugiyono:2013). Suatu kuesioner dilakukan valid jika pernyataan pada kuesioner mampu untuk mengungkapkan sesuatu yang akan diukur oleh kuesioner tersebut. Dasar pengambilan keputusan valid atau tidaknya pernyataan oleh Sugiyono (2013:126) :

Jika $r$ positif, serta $r \geq 0,30$ maka item pertanyaan tersebut valid.

Jika $r$ negative, serta $r \leq 0,30$, maka item pernyataan tersebut tidak valid.

Untuk mengetahui valid tidaknya masing-masing item pertanyaan dalam instrumen dilakukan uji validitas dengan rumus karl pearson correlation product. Dengan rumus sebagai berikut :

Keterangan :

$$
r_{X y}=\frac{N \sum X Y-\left(\sum X\right)\left(\sum Y\right)}{\left.\sqrt{\left[N \sum X^{2}-\left(\sum X\right)^{2}\right]\left[N \sum Y^{2}\right.}-\left(\sum Y\right)^{2}\right]}
$$

(Sugiyono,2013)

$$
\begin{aligned}
& \mathrm{R}=\text { koefisien korelasi product momen } \\
& \mathrm{X}=\text { skor masing-masing item pertanyaan } \\
& \mathrm{Y}=\text { total skor item-item pertanyaan } \\
& \mathrm{N}=\text { banyak data atau banyak responden }
\end{aligned}
$$

Namun untuk memudahkan uji validitas data maka peneliti menggunakan program SPSS versi 22 for window dalam pengolahan data.

\section{Uji Realibilitas}

Uji reliabilitas adalah suatu uji menunjukan sejauh mana pengukuran ini dapat memberikan hasil relatif tidak beda bila dilakukan pengulangan pengukuran terhadap subjek yang sama. Pengujian reliabilitas dilakukan dengan menggunakan Alpha atau Cronbach's Alpa. Dasar pengambilan keputusan (Sugiyono, 2010 : 154):

1. Koefisien Cronbach's Alpha kurang dari 0,6 maka mengindikasikan reliabilitas item-item pertanyaan yang buruk.

2. Koefisien Cronbach's Alpha dengan range 0,7 dapat diterima.

3. Koefisien Cronbach's Alpha yang lebih baik dari 0,8 adalah baik. 


\section{Teknik Analisis Regresi Linear Berganda}

Analisis kuantitatif dengan menggunakan alat analis regresi berganda adalah suatu analisis yang digunakan oleh peneliti, bila peneliti bermaksud meramalkan bagaimana keadaan (naik turunnya) variabel dependen, bila dua variabel atau lebih variabel sebagai faktor prediktor, sebagaimana dikutip dari (sugiyono, 2013:19). Persamaan regresi tersebut adalah sebagai berikut:

$$
\begin{aligned}
& \mathrm{Y}=\mathrm{a}+\mathrm{b}_{1} \mathrm{x}_{1}+\mathrm{b}_{2} \mathrm{x}_{2}+\mathrm{e} \text { (Sugiyono, } 2003: 135 \text { ) } \\
& \text { Dimana: } \\
& \mathrm{Y} \quad=\text { loyalitas pelanggan } \\
& \mathrm{X}_{1} \quad=\text { customer experience } \\
& \mathrm{X}_{2} \quad=\text { trust } \\
& \text { a } \quad=\text { konstanta } \\
& \mathrm{b}_{1}, \mathrm{~b}_{2}=\text { koefisien regresi } \mathrm{x}_{1}, \mathrm{x}_{2} \\
& \text { e }=\text { eror }
\end{aligned}
$$

\section{Uji T (Parsial)}

Menurut Ghozali (2012: 98) Uji beda t-test digunakan untuk menguji seberapa jauh pengaruh variabel independen yang digunakan dalam penelitian ini secara individual dalam menerangkan variabel dependen secara parsial. Tujuan dari uji parsial adalah untuk mengetahui seberapajauh pengaruh dari variabel independen (X) terhadap variable dependen (Y) secara parsial. Pengujian hipotesis akan dilakukan dengan menggunakan tingkat signifikansi sebesar0,05 $(\alpha=5 \%)$ atau tingkat keyakinan sebesar 0,95 . Hipotesis dirumuskan sebagai berikut : Ho : bi $=0$ HA : bi $\neq 0$

Ketentuan dalam pengujian ini adalah sebagai berikut :

1) Jika tingkat signifikansi $\leq 5 \%$, Ho ditolak dan Ha diterima

2) Jika tingkat signifikansi $\geq 5 \%$, Ho diterima dan Ha ditolak

\section{Uji F (Simultan)}

Menurut Ghozali (2012: 98) Uji Statistik F pada dasarnya menunjukkan apakah semua variabel independen atau variabel bebas yang dimasukkan dalam model mempunyai pengaruh secara bersama-sama terhadap variabeldependen atau variabel terikat. Pada pengujian ini juga menggunakan tingkat signifikansi sebesar5\% atau 0,05. Prosedur Uji F ini adalah sebagai berikut :

1) Menentukan hipotesis nol maupun hipotesis alternatifnya :

Ho : $b 1=b 2=b 3=0$, berarti tidak ada pengaruh $X 1, X 2$, terhadap $Y$

$\mathrm{Ha}: \mathrm{b} 1 \neq \mathrm{b} 2 \neq \mathrm{b} 3 \neq 0$, berarti ada pengaruh $\mathrm{X} 1, \mathrm{X} 2$, terhadap $\mathrm{Y}$

2) Membuat keputusan uji FJika nilai F lebih besar dari pada 4 maka Ho ditolak pada derajat kepercayaan 5\%, dengan kata lain hipotesis alternatif(Ha) diterima, yang menyatakan bahwa semua variabelindependen secara serentak dan signifikan mempengaruhivariabel dependen.

\section{HASIL PENELITIAN DAN PEMBAHASAN}

\section{Hasil Uji Validitas dan Reliabilitas}

Untuk menguji validitas dan reabilitas instrument, penulis menggunakan analisis dengan SPSS versi 22 for windows. Uji validitas dilakukan untuk mengetahui 
apakah suatu item pertanyaan layak atau tidak layak untuk digunakan sebagai alat ukur dalam melakukan penelitian. Berikut adalah hasil dari pengujian validitas :

Tabel 4.1 Uji Validitas

\begin{tabular}{|c|l|l|l|l|}
\hline Variabel & $\begin{array}{l}\text { No } \\
\text { Pernyataan }\end{array}$ & $\begin{array}{l}\mathbf{R} \\
\text { Hitung }\end{array}$ & $\mathbf{R}$ & Keterangan \\
\hline \multirow{4}{*}{$\begin{array}{c}\mathbf{X}_{1} \\
\text { Customer }\end{array}$} & 1 & 0,607 & 0,3 & Valid \\
\cline { 2 - 5 } Experience & 2 & 0,708 & 0,3 & Valid \\
\cline { 2 - 5 } & 3 & 0,416 & 0,3 & Valid \\
\cline { 2 - 5 } & 4 & 0,726 & 0,3 & Valid \\
\hline $\mathbf{X}_{2}$ & 5 & 0,558 & 0,3 & Valid \\
\cline { 2 - 5 } Trust & 2 & 0,667 & 0,3 & Valid \\
\cline { 2 - 5 } & 3 & 0,419 & 0,3 & Valid \\
\hline \multirow{3}{*}{$\begin{array}{c}\text { Yoyalitas } \\
\text { Pelanggan }\end{array}$} & 1 & 0,305 & 0,3 & Valid \\
\cline { 2 - 5 } & 2 & 0,3700 & 0,3 & Valid \\
\cline { 2 - 5 } & 3 & 0,473 & 0,3 & Valid \\
\cline { 2 - 5 } & 4 & 0,660 & 0,3 & Valid \\
\hline
\end{tabular}

Sumber : Hasil Penelitian 2020

Dari tabel diatas dapat dilihat bahwa $r \geq 0,30$. Ini menunjukkan bahwa item dari setiap pernyataan kuesioner masing-masing variabel tersebut adalah valid dan layak untuk digunakan dalam penelitian ini. Artinya item dari setiap pernyataan tersebut mampu mengukur dan menjelaskan variabel secara tepat.

\section{Uji Reliabilitas}

Untuk menguji reliabilitas instrument, penulis menggunakan analisis SPSS 22. Berikut hasil pengujian reliabilitas, untuk tingkat reliabel dilakukan uji reliabel, apabila Cronbach's Alpa lebih lebih besar dari 0,60 maka butir pertanyaan tersebut dikatakan reliabel.

\begin{tabular}{|c|c|c|c|}
\hline Variabel & \begin{tabular}{|l} 
No \\
Pernyataan
\end{tabular} & $\begin{array}{r}\text { Cronbach' } \\
\text { s Alpha }\end{array}$ & Keterangan \\
\hline \multirow{5}{*}{$\begin{array}{c}\mathrm{X}_{1} \\
\text { Customer } \\
\text { Experience }\end{array}$} & 1 & \multirow{5}{*}{0,773} & Reliabel \\
\hline & 2 & & Reliabel \\
\hline & 3 & & Reliabel \\
\hline & 4 & & Reliabel \\
\hline & 5 & & Reliabel \\
\hline \multirow{3}{*}{$\begin{array}{c}\mathrm{X}_{2} \\
\text { Trust }\end{array}$} & 1 & \multirow{3}{*}{0,737} & Reliabel \\
\hline & 2 & & Reliabel \\
\hline & 3 & & Reliabel \\
\hline \multirow{4}{*}{$\begin{array}{c}\mathbf{Y} \\
\text { Loyalitas } \\
\text { Pelanggan }\end{array}$} & 1 & \multirow{4}{*}{0,738} & Reliabel \\
\hline & 2 & & Reliabel \\
\hline & 3 & & Reliabel \\
\hline & 4 & & Reliabel \\
\hline
\end{tabular}

Sumber : Hasil Penelitian 2020 
Tabel 4.2 diatas menunjukkan hasil pengujian terhadap masing-masing varibel, dapat disimpulkan bahwa semua variabel menunjukkan sebagai suatu ukuran yang reliabel dengan Cronbach's Alpa lebih > dari 0,60. Hal ini berarti instrument penelitian kuesioner memiliki hasil yang reliabel (konsisten) sehingga instrument ini layak untuk digunakan dalam penelitian.

\section{Hasil Analisis Regresi Linier Berganda}

Analisis regresi berganda digunakan untuk mengetahui besarnya pengaruh customer experience, dan trust terhadap loyalitas pelanggan KFC di Kota Bengkulu. Perhitungan statistik dalam analisis regresi berganda dijelaskan pada tabel berikut ini :

Tabel 4.3

Hasil Uji Regresi Linier Berganda Coefficients $^{\mathrm{a}}$

\begin{tabular}{|c|c|c|c|c|c|c|}
\hline \multirow{2}{*}{\multicolumn{2}{|c|}{ Model }} & \multicolumn{2}{|c|}{$\begin{array}{l}\text { Unstandardized } \\
\text { Coefficients }\end{array}$} & \multirow{2}{*}{$\begin{array}{l}\text { Standardiz } \\
\text { ed } \\
\text { Coefficien } \\
\text { ts } \\
\begin{array}{l}\text { Bet } \\
\text { a }\end{array}\end{array}$} & \multirow[t]{2}{*}{$\mathrm{T}$} & \multirow[t]{2}{*}{ Sig. } \\
\hline & & B & Std. Error & & & \\
\hline \multirow[t]{3}{*}{1} & (Constant) & 2.244 & 1.169 & & 1.920 & .058 \\
\hline & $\begin{array}{l}\text { customer } \\
\text { experience }\end{array}$ & .292 & .071 & 322 & 4.090 & .000 \\
\hline & Trust & 675 & .096 & .553 & 7.024 & .000 \\
\hline
\end{tabular}

a. Dependent Variable: loyalitas pelanggan

Sumber:HasilPenelitian dan diolah, 2020

Dari hasil perhitungan regresi linear berganda dengan menggunakan program SPSS 22 for windows maka dapat diperoleh persamaan regresi linier berganda sebagai berikut :

$$
Y=2,244+0,292 X_{1}+0,675 X_{2}
$$

Persamaan regresi tersebut dapat dijelaskan sebagai berikut :

1. Nilai konstanta 2,244 mempunyai arti bahwa apabila variabel customer experience $\left(\mathrm{X}_{1}\right)$, dan trust $\left(\mathrm{X}_{2}\right)$ terhadap loyalitas pelanggan $(\mathrm{Y})$, sama dengan nol maka variabel loyalitas pelanggan akan tetap sebesar 2,244.

2. Pengaruh customer experience $\left(\mathrm{X}_{1}\right)$ terhadap loyalitas pelanggan $(\mathrm{Y})$ Nilai koefesien regresi variabel $\mathrm{X}_{1}$ (customer experience) adalah sebesar 0,292 artinya apabila $\mathrm{X}_{1}$ (customer experience) mengalami kenaikan sebesar satusatuan dengan asumsi $\mathrm{X}_{2}$ tetap maka $\mathrm{Y}$ (loyalitas pelanggan) juga akan mengalami kenaikan sebesar 0,292 kali. Hal ini menggambarkan bahwa customer experience yang ada di KFC dalam hal menyenangkan pelanggan akan meningkatkan loyalitas pelanggan KFC di Kota Bengkulu.

3. Pengaruh trust $\left(\mathrm{X}_{2}\right)$ terhadap loyalitas pelanggan $(\mathrm{Y})$ 
Nilai koefesien regresi variabel $\mathrm{X}_{2}$ (trust) adalah sebesar 0,675 artinya apabila $\mathrm{X}_{2}$ (trust) mengalami kenaikan sebesar satu-satuan dengan asumsi $\mathrm{X}_{1}$ tetap maka Y (loyalitas pelanggan) juga akan mengalami kenaikan sebesar 0,675 kali. Hal ini menggambarkan bahwa loyalitas pelanggan akan meningkat pada KFC di Kota Bengkulu apabila trust ditingkatkan.

\section{Hasil Uji Koefisien Determinasi $\left(\mathbf{R}^{2}\right)$}

Koefisien determinasi ini digunakan untuk mengetahui seberapa besar pengaruh variabel-variabel bebas memiliki pengaruh terhadap variabel terikatnya. Nilai koefisien determinasi ditentukan dengan nilai $R$ square.

Tabel 4.4

Koefesien Determinasi

Model Summary

\begin{tabular}{|l|c|c|c|c|}
\hline Model & R & R Square & $\begin{array}{c}\text { Adjusted } \\
\mathrm{R} \\
\text { Square }\end{array}$ & Std. Error of the Estimate \\
\hline 1 & & .63 & .624 & .939 \\
$\mathrm{a}$ & 1 & & \\
\hline
\end{tabular}

a. Predictors: (Constant), Trust, Customer Experience

Sumber: Hasil Penelitian dan diolah, 2020

Dari hasil perhitungan dengan menggunakan SPSS dapat diketahui nilai koefesien determinasi dari nilai $\mathrm{R}^{2}$ ( $\mathrm{R}$ Square) yaitu sebesar 0,631. Hal ini berarti bahwa costumer experience $\left(\mathrm{X}_{1}\right)$, dan trust $\left(\mathrm{X}_{2}\right)$ berpengaruh terhadap loyalitas pelanggan (Y) sebesar $63,1 \%$ sedangkan sisanya 36,9\% dipengaruhi oleh variabel-variabel lainnya yang tidak diteliti dalam penelitian ini.

\section{Hasil Uji T (T-Test)}

Hasil pengujian hipotesis uji t dengan menggunakan SPSS 22 adalah sebagai berikut :

\section{Tabel 4.5 Hasil Uji t \\ Coefficientsa}

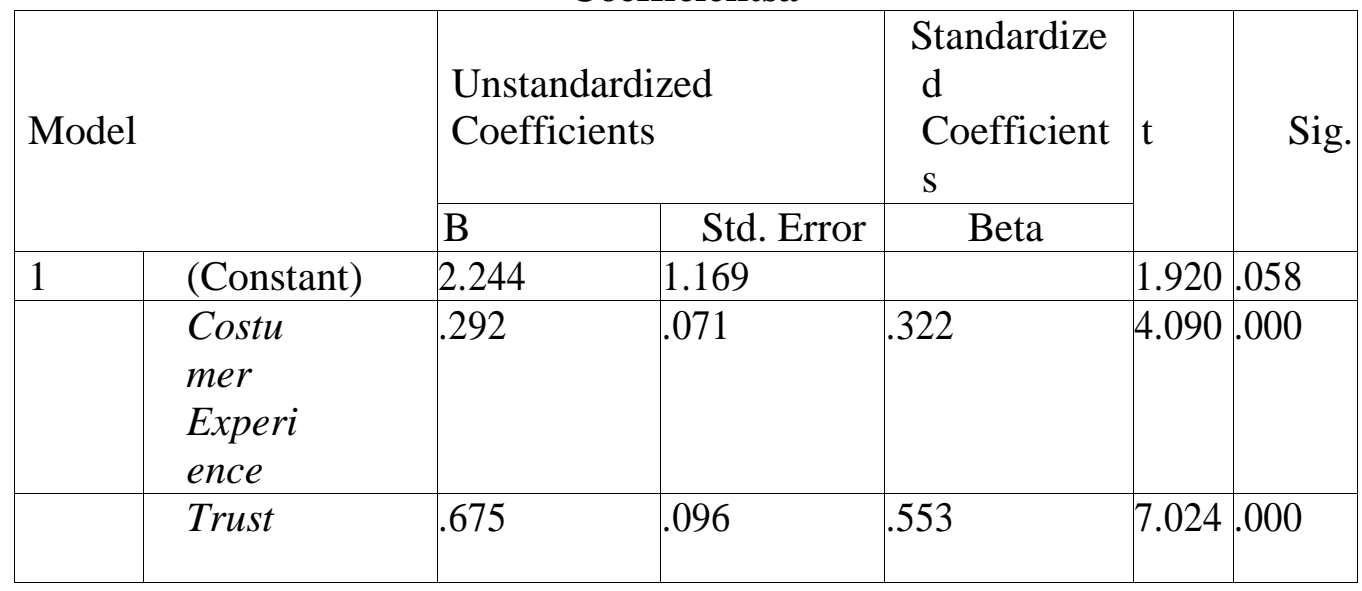

a. Dependent Variable: loyalitas pelanggan

Sumber: Hasil Penelitian dan diolah, 2020 
Dari hasil perhitungan di atas maka dapat dijelaskan bahwa $\mathrm{X}_{1}$ (Customer Experience) menunjukkan nilai signifikansi sebesar $0,000<0,05$, karena nilai signifikansi lebih kecil dari 0,05 , maka $\mathrm{H} 0$ ditolak dan Ha diterima. Artinya $\mathrm{X}_{1}$ (Customer Experience) memiliki pengaruh yang positif dan signifikan terhadap Loalitas Pelanggan(Y). Hasil pengujian untuk variabel $\mathrm{X}_{2}$ (Trust) menunjukkan nilai signifikansi sebesar $0,000<0,05$. Karena nilai signifikansi lebih kecil dari 0,05, maka $\mathrm{H} 0$ ditolak dan Ha diterima. Artinya $\mathrm{X}_{2}$ (Trust) memiliki pengaruh yang positif dan signifikan terhadap Loyalitas Pelanggan (Y).

\section{Hasil Uji Simultan (Uji F)}

Dalam penelitian ini pengujian hipotesis dimaksudkan untuk mengukur besarnya pengaruh customer experience $\left(\mathrm{X}_{1}\right)$, dan trust $\left(\mathrm{X}_{2}\right)$ berpengaruh terhadap loyalitas pelanggan (Y) maka digunakan uji F. Berdasarkan hasil pengujian hipotesis Uji Anova atau uji $\mathrm{F}$ terlihat pada tabel berikut

\section{Tabel 4.6 Hasil Uji F}

ANOVA $^{\mathrm{a}}$

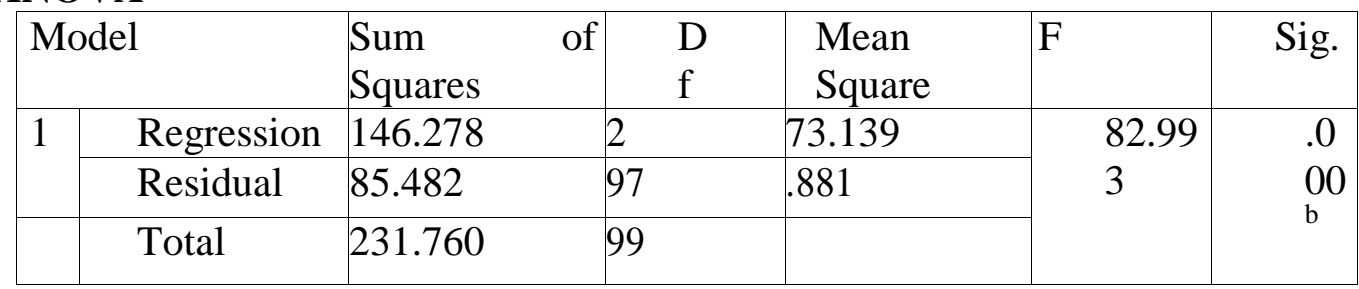

a. Dependent Variable: loyalitas pelanggan

b. Predictors: (Constant), costumer experience, trust

Sumber: Hasil Penelitian dan diolah, 2020

Hasil perhitungan statistik menunjukkan nilai signifikansi sebesar 0,000<0,05. Karena nilai signifikansi di bawah 0,05 menunjukkan bahwa secara bersama-sama $\mathrm{X}_{1}$ (Customer Experience) dan $\mathrm{X}_{2}$ (Trust) mempunyai pengaruh yang positif dan signifikan terhadap Loyalitas Pelanggan (Y). Maka berdasarkan hasil uji simultan maka H0 ditolak dan Ha diterima, antara Variabel-variabel bebas yaitu $\mathrm{X}_{1}$ (Customer Experience), dan $\mathrm{X}_{2}$ (Trust), mempunyai pengaruh yang signifikan secara bersama-sama terhadap Loyalits Pelanggan (Y).

\section{PEMBAHASAN}

\section{Pengaruh Customer Experience Terhadap Loyalitas Pelanggan}

Hasil penelitian menunjukkan bahwa nilai signifikan untuk variabel Customer Experience sebesar 0,000, karena nilai tersebut lebih kecil dari 0,05 sehingga $\mathrm{Ha}$ diterima dan Ho ditolak yang berarti Customer Experience berpengaruh signifikan terhadap loyalitas pelanggan. Dengan demikian, hipotesis yang menyatakan bahwa Customer Experience berpengaruh signifikan terhadap loyalitas pelanggan terbukti. Hal ini menggambarkan dengan adanya Customer Experience di restoran cepat saji KFC Bengkulu untuk memberikan kesan baik pada produknya akan memunculkan ketertarikan dari konsumen untuk loyal terhadap produk KFC 
karena kelebihan dari KFC akan di katakan konsumen dari word of mouth. Hal ini akan meningkatkan loyalitas pelanggan untuk produk di KFC Bengkulu.

\section{Pengaruh Trust Terhadap Loyalitas Pelanggan}

Hasil penelitian menunjukkan bahwa nilai signifikan untuk variabel Trust sebesar 0,000, nilai tersebut lebih kecil dari 0,05 sehingga Ha diterima dan Ho ditolak yang berarti Trust berpengaruh signifikan terhadap loyalitas pelanggan. Dengan demikian, hipotesis yang menyatakan bahwa Trust berpengaruh yang signifikan terhadap loyalitas pelanggan terbukti. Berdasarkan hasil penelitian, Trust KFC telah melekat di pikiran konsumen sehingga pada saat konsumen ingin membeli ayam goreng yang terpikir hanyalah ingin membeli di KFC. Merek restoran cepat saji yaitu KFC merupakan merek yang sudah dikenal luas oleh masyarakat.

\section{Pengaruh Customer Experience, dan Trust Terhadap Loyalitas Pelanggan}

Berdasarkan hasil uji $\mathrm{F}$ menunjukkan bahwa ada pengaruh yang signifikan antara variabel Customer Experience (X1), dan Trust (X2) terhadap loyalitas pelanggan (Y). Hal ini berarti bahwa variabel independen dan dependen memiliki hubungan yang kuat dan pengaruhnya positif. Customer Experience dan Trust merupakan penentu loyalitas pelanggan yang artinya semakin meningkatnya Customer Experience dan Trust maka semakin meningkat juga loyalitas pelanggan. KFC yang mengutamakan Customer Experience dan Trust yang baik akan memberikan dampak positif terhadap loyalitas pelanggan. Customer Experience dan Trust yang diberikan oleh pihak KFC memberikan kesan sendiri bagi konsumen untuk datang kembali ke KFC tersebut. Hal ini berarti bahwa Customer Experience dan Trust merupakan faktor yang perlu diperhitungkan dalam rangka meningkatkan loyalitas pelanggan KFC di Kota Bengkulu.

\section{KESIMPULAN DAN SARAN}

\section{Kesimpulan}

1. Hasil pengujian untuk variabel $\mathrm{X}_{1}$ (Customer Experience) menunjukkan nilai signifikansi sebesar $0,000<0,05$. Karena nilai signifikansi lebih kecil dari $0,05, \mathrm{X}_{1}$ (Customer Experience) memiliki pengaruh yang positif dan signifikan terhadap Loyalitas Pelanggan (Y).

2. Hasil pengujian untuk variabel $\mathrm{X}_{2}$ (Trust) menunjukkan nilai signifikansi sebesar $0,000<0,05$. Karena nilai signifikansi lebih kecil dari 0,05, $\mathrm{X}_{2}$ (Trust) memiliki pengaruh yang positif dan signifikan terhadap Loyalitas Pelanggan (Y).

3. Berdasarkan hasil pengujian hipotesis dengan uji $\mathrm{F}$, nilai signifikansi sebesar $0,000<0,05$ dan tingkat signifikansi di bawah 0,05 menunjukkan bahwa secara bersama-sama Customer Experience $\left(\mathrm{X}_{1}\right)$, dan Trust $\left(\mathrm{X}_{2}\right)$ mempunyai pengaruh yang positif dan signifikan terhadap loyalitas pelanggan $(\mathrm{Y})$.

4. Nilai koefesien determinasi dari nilai $\mathrm{R}^{2}$ ( $\mathrm{R}$ Square) yaitu sebesar 0,631 . Hal ini berarti bahwa Customer Experience $\left(\mathrm{X}_{1}\right)$, dan Trust $\left(\mathrm{X}_{2}\right)$ berpengaruh terhadap loyalitas pelanggan $(\mathrm{Y})$ sebesar $63,1 \%$ sedangkan sisanya 36,9\% dipengaruhi oleh variabel-variabel lainnya yang tidak diteliti dalam penelitian ini. 


\section{Saran}

Diharapkan untuk KFC di Kota Bengkulu untuk meningkatkan kepercayaan pelanggan, terutama mengenai indikator karyawan KFC dimana orang-orang yang ahli dibidangnya juga memberikan pengaruh terhadap kepercayaan pelanggan karena indikator inilah yang memiliki nilai yang rendah dibandingkan dengan indikator yang lain perlu ditingkatkan lagi dari segi skill dan harus memiliki pengetahuan yang luas tentang pelayanan konsumen agar kedepannya lebih baik lagi karena kepercayaan konsumen bisa memengaruhi hubungan jangka panjang.

\section{DAFTAR PUSTAKA}

Alma, Buchari. 2007. Manajemen Pemasaran dan Pemasaran Jasa. Bandung: Alfabeta

Barnes, J.G. 2011. Secrets of Customer Relationship Management (Rahasia Manajemen Hubungan Pelanggan). Edisi II. Yogyakarta: Andi Offset.

Deni Pranoto, 2014. Pengaruh Kepercayaan Dalam Pembelian, Gramedia, Jakarta.

Gefen,D.,Karahanna,E. \& Straub, D.W. 2003. Trust and TAM in Online Shopping: An Integrated Model. Management Information System Quarterly, 27(1): 51-90.

Griffin Jill. 2010. Customer Loyalty How To Earn it, How Keep It I. Kentucky: McGraw Hill.

Hur et al. (2011). A Structural Model of the Relation- ships Between Sport Website Quality, E- Satisfaction, and E-Loyalty. Journal of Sport Management. 25, pp. 458-473.

Kotler \& Keller. 2010. Manajemen Pemasaran. Edisi -13, Jilid 1. Jakarta: Erlangga.

Kuncoro, Mudrajad.2009. Metode Riset Untuk Bisnis \& Ekonomi. Edisi 3. Jakarta: Erlangga.

Meyer, Christoper dan Andre Schwager. 2007. Understanding Customer Experience. Harvard Business Review.

Ndubisi, Nelsen Oly. (2007). “ Relationship Marketing and Customer Loyalty” Journal of Marketing Intellgence \& Planning. Vol 25, No. 1, pp.98-106. 
Nasermoadeli, Amir., Choon-Ling, Kwek., Maghnati, Farshad. (2012). Evaluating the Impact of Customer Experience on Repurchase Intention. International Journal of Business and Management Vol.8.

Sangadji, Etta., dan Sopiah. 2013. Perilaku Konsumen. Yogyakarta : CV. Andi Offset.

Sheth, Jagdish., \& Mittal Banwari. (2004). Customer Behavior: A Manajerial Persepective, edisi kedua. Thompson South Westem. USA.

Sugiyono. 2003. Metode Penelitian. Bandung: Alfabeta.

Terblanche,N.S. 2009, Customer Experience Interactions, Relationship and Corporate Reputation. Journal Of General Management.

Tjiptono, Fandy dan Chandra, Gregorius. 2011. Service, Quality, dan Satisfaction Edisi 3. Yogyakarta: Penerbit Andi. 